\title{
Influence of Sipinsur Ecotourism Area Business Opportunity on Regional Development in Humbang Hasundutan Regency
}

\author{
Sarintan Efratani Damanik \\ Faculty of Agriculture, Forestry Study Program, Simalungun University, Indonesia \\ Corresponding authoremail: damanikintan@yahoo.com \\ Rozalina \\ Faculty of Agriculture, Forestry Study Program, Simalungun University, Indonesia \\ Email: rozalinalubis@gmail.com \\ Meylida Nurrachmania \\ Faculty of Agriculture, Forestry Study Program, Simalungun University, Indonesia \\ Email: meylidanurrachmania@gmail.com
}

\begin{abstract}
The potential of natural resources strongly supports the development of sectors in the region and results in business opportunities, can also increase the income of the community around the ecotourism site. The research analyzed the influence of business opportunities in sipinsur ecotourism area. Research methods using simple linear regression. The results showed that business opportunities have a positive and significant effect on regional development in Humbang Hasundutan Regency. As an entrepreneur must be observant to take advantage of business opportunities so that the business built will not be wasted and it takes hard work, and the business opportunity is a business that can be done using small capital or using large capital. Empowering local communities by including them in various ecotourism activities, especially in business opportunities. Therefore, the government needs to increase the socialization of programs and the active role of the community so that the community has the means to accommodate their aspirations, and the community needs to be fostered intensively to become a community that is aware of ecotourism, namely the community that not only utilizes the results of ecotourism development but also takes responsibility in maintaining natural sustainability.
\end{abstract}

Keywords---business opportunities, ecotourism areas, regional and community development.

\section{Introduction}

The development of ecotourism industry of an area is highly dependent on the number of tourists who enter and come to the region, therefore ecotourism must be supported by facilities and infrastructure and increase optimal utilization in tourist destinations, with the optimal utilization of the area, the ecotourism industry can develop and progress well. Indonesia is rich in natural beauty has a very beautiful scenery and supports the development of the tourism industry sector. As an island nation, Indonesia's natural potential is very possible to be developed, especially the ecotourism tourism industry is very likely (Scheyvens, 1999; Fuller et al., 2005; Lindberg et al., 1996).

Along with the tourism industry that is currently encouraged, the government makes policies in an effort to realize the rights and autonomy of the region that is increasingly running dynamically and responsibly in development, the local government strives in the development of ecotourism in their respective regions and will be more important meaning and role in encouraging regional development in the future. This has consequences for the region to strive for various steps optimally to explore and utilize the potential of tourism as one of the sources of regional income, especially the native income of the region to support development. 
Humbang Hasundutan Regency is located in North Sumatra, Indonesia. This district has been inaugurated on July 28, 2003, and has an area of 2,335.33 $\mathrm{km}^{2}$, with the capital Dolok Sanggul, this district has an administrative boundary with other districts that are north bordered by Samosir Regency, east of North Tapanuli Regency, south of Central Tapanuli Regency and west of West Pakpak Regency.

Humbang Hasundutan regency as the newly inaugurated district has a lot of natural resources potential. The potential of natural resources when optimized is very supportive of the development of natural tourism and resulting in business opportunities can also increase the income of the community around tourism sites and tourist attractions. Humbang Hasundutan regency has a very exotic ecotourism, both known by the community and the unknown and still potential and untouched development as it is like an ecotourism location. Ecotourism natural resources are very diverse including natural beauty so it is believed that the potential is able to support the improvement of the welfare of the community, especially the surrounding community (Gurung \& Seeland, 2008; Das \& Chatterjee, 2015).

One of the attractions is the ecotourism object. The most popular type of tourism by tourists is Sipinsur ecotourism. The tourism sector in this area has received maximum handling so that many tourists have glanced at its natural potential. The protected forest located in Sipinsur if managed by KPH XIII and well developed with the beauty of the natural panorama of Lake Toba that is widely found in this area, can be an attraction for tourists to visit the Humbang Hasundutan area as a recreational destination or ecotourism sightseeing. Based on the description above, it is necessary to find a solution to the existing problem, namely how business opportunities and business opportunity solutions in the area of sipinsur ecotourism object.

\section{Research Methods}

The object of research in this study is sipinsur ecotourism area of Humbang Hasundutan Regency. The subjects to be studied are small business traders, tourists, in the ecotourism area of Sipinsur Humbahas Regency. Data collection techniques conducted purposive sampling the number of respondents is 155 respondents, determined by the formula Solvin namely:

$$
n=\frac{N}{1+\mathrm{Ne}^{2}}
$$

Description:

$\mathrm{n}=$ Number of respondents

$\mathrm{N}=$ Population size within a certain time

$\mathrm{e}=$ Approximate error rate

In this study the data used is primary data obtained from visitors, small and medium enterprises secondary data collected from the relevant Office in Humbahas Regency and tourist panoramas in Humbang Hasundutan Regency.

\section{Research and Discussion Results}

\section{Business Opportunities}

From Table 1 obtained the regression equation obtained $\mathrm{Y}=3,337+0.481 \mathrm{X} 1$, it is seen that the business opportunities are in the direction of regional development. The result of the equation can be interpreted the value of 3,337 gives the sense that if the business opportunity does not change (constant), then the value of wialayah will increase by 3,337 and the value of business opportunity regression koefisen 0.481 gives the sense that if the business opportunity is increased, then the development of the region will increase by 0.481 . 
Table 1

Regression Test

\begin{tabular}{|c|c|c|c|c|c|}
\hline \multirow[t]{2}{*}{ Model } & \multicolumn{2}{|c|}{$\begin{array}{l}\text { Unstandardized } \\
\text { Coefficients }\end{array}$} & $\begin{array}{l}\text { Standardized } \\
\text { Coefficients }\end{array}$ & \multirow[t]{2}{*}{$\mathrm{t}$} & \multirow[t]{2}{*}{ Sig. } \\
\hline & B & Std. Error & Beta & & \\
\hline (Constant) & 3.337 & 72.304 & & 2.046 & .046 \\
\hline $\begin{array}{ll}1 & \text { Business } \\
& \text { Opportunities }\end{array}$ & .481 & 191 & .824 & 2.523 & .086 \\
\hline
\end{tabular}

a. Dependent Variable: Regional Development

$\mathrm{T}$ count value for business opportunity variable $(2,523)$ bigger with $\mathrm{t}$-table $(1,654)$, based on the results obtained, business opportunities have a positive and significant effect on the development of the.

Table 2

Anova

\begin{tabular}{lllllll}
\hline Model & & Sum of Squares & df & Mean Square & F & Sig. \\
\hline \multirow{2}{*}{1} & Regression & 55148.940 & 1 & 55148.940 & 6.364 & $.086^{\mathrm{b}}$ \\
& Residual & 25995.860 & 3 & 8665.287 & & \\
& Total & 81144.800 & 4 & & & \\
\hline
\end{tabular}

a. Dependent Variable: Regional Development

b. Predictors: (Constant), Business Opportunities

$F_{\text {calculate value }}>F_{\text {.table }}(6,363>3,06)$ that the business opportunities of sipinsur ecotourism areas have a positive and significant impact on the development of the.

Table 3

Coefficient of Determination

\begin{tabular}{|c|c|c|c|c|c|c|c|c|}
\hline \multirow[t]{3}{*}{ Model } & \multirow[t]{3}{*}{$\mathrm{R}$} & R & Adjusted & Std. Error & Change & tatistics & \multirow{3}{*}{ df1 df2 } & \\
\hline & & Square & R Square & of the & $\mathrm{R}$ & $\mathrm{F}$ & & Sig. $\quad F$ \\
\hline & & & & Estimate & $\begin{array}{l}\text { Square } \\
\text { Change }\end{array}$ & Change & & Change \\
\hline 1 & $.824^{\mathrm{a}}$ & .680 & .573 & 93.08752 & .680 & 6.364 & 3 & .086 \\
\hline
\end{tabular}

a. Predictors: (Constant), Business Opportunities

From the table above known coefficient of determination (R Square) of 0.680 or $68 \%$. The results mean that business opportunities can explain the development of the region by $68 \%$, while the remaining $32 \%$ is explained by other variables that were not included in this study.

In running a business, must know about our business in a lot, both internal factors and external factors, these factors should be known because to minimize the risks that can come to our business. In addition, we must also know about the potential of the business itself, so that later the business can be developed into a greater business potential is an ability that comes from within the individual. Aside from the potential of yourself, there are still other factors that can support success in trying, namely the first existence of the entrepreneur's soul. Someone who has an entrepreneur's soul must be resilient. A resilient entrepreneur must also be brave in taking risks in order for his business to grow. The second is the business capital, the capital used in starting the business to be carried out. The large or small amount of capital used is very influential on the success of the business carried out. The third is a business opportunity. As an entrepreneur must be observant to take advantage of business opportunities to be implemented, understanding business opportunities in the sense that the business built will not be in vain. Many entrepreneurs also start their business by opening a business by looking at several small business opportunities that can later be developed with small capital. This is in accordance with the results of research from Juma \& Timmer, (2003) business opportunities and entrepreneurial development is an indispensable requirement by the government to 
develop the potential of people who have an entrepreneurial spirit individually, especially at this time business opportunities for the community in the field of ecotourism is highly prioritized (Klar, 2012; Berkes \& Seixas, 2004; (Otsuki, 2007; Bredeson et al., 2009).

Sipinsur ecotourism business opportunities affect $68 \%$ of regional development in Humbang Hasundutan Regency. The economic benefits that have been obtained from ecotourism should be utilized efficiently and should be supported especially to preserve the environment. These ecotourism activities that have benefited economically can be used to support conservation activities, especially natural and cultural wealth in the region. The development of tourism industry through ecotourism based on the natural environment and its main attraction will greatly implicate the preservation of the environment. Ecotourism in principle needs to be handled and managed primarily based on sustainable principles, especially financially because ecotourism is different from other forms of tourism in terms of its dependence on the protection of ecosystems and cultural elements contained therein. This was echoed by Nugroho et al. (2016) an ecotourism service activity in the village can be a solution to problems in the field of agricultural development. Local people who are able to do business ecotourism services will enjoy prosperity. (Ghorbanzadeh \& Niloufar, 2019; Ibrahim et al., 2019). In turn, this will result in incentives to preserve agricultural production and build participation and empower local communities.

\section{Business Opportunity Solutions}

\section{Community Participation}

People who live around the ecotourism destination area have an important role, especially in supporting the success and development of ecotourism. Community participation, especially in terms of maintaining environmental resources that are the main attraction in ecotourism can not be simply ignored. The most important thing is the effort to empower the local community by including them in various ecotourism activities, especially in business opportunities. People should be observant in seeing opportunities in doing business, especially in choosing a strategic location so that there will be many ecotourism visitors who see the products or services offered, sell products that are appropriate or related to the place of ecotourism, always pay attention whenever the visitors are crowded and pay attention to the capital to be issued.

\section{Capital}

Capital is a very important thing in conducting business activities, by having capital it will be easier in carrying out business, and can take into account the profits that will be obtained and run the business consistently.

\section{Manager}

Ecotourism managers should urge the community to always be willing to participate actively and positively, especially in the development of ecotourism by maintaining the environment around them. Ecotourism can run and develop well, then the local community around the ecotourism destination should have absolute responsibility and access to the ecotourism area, the development of sustainable ecotourism can not be realized properly if the local people feel ignored from the activity, only used when needed and they feel threatened by ecotourism activities.

\section{Conclusions}

The business opportunities of Sipinsur ecotourism area have a positive and significant effect on the development of the area in Humbang Hasundutan Regency. Recommendations: (1) the government improves the socialization of programs and the active role of non-governmental groups so that the community has the means to accommodate their aspirations, (2) The community needs to be fostered intensively to become a community that is aware of ecotourism, namely the community that not only utilizes the results of ecotourism development but is also responsible in maintaining natural sustainability

\section{Acknowledgments}

Authors would like to thank you University of Simalungun that has supported this research. 


\section{References}

Berkes, F., \& Seixas, C. S. (2004). Lessons from community self-organization and cross-scale linkages in four Equator Initiative projects.

Bredeson, P. V., Klar, H. W., \& Johansson, O. (2009). Superintendents as collaborative learners in communities of practice: A sociocultural perspective on professional learning. Journal of School Public Relations, 30(2), 128149.

Das, M., \& Chatterjee, B. (2015). Ecotourism: A panacea or a predicament?. Tourism management perspectives, 14, 3-16. https://doi.org/10.1016/j.tmp.2015.01.002

Fuller, D., Buultjens, J., \& Cummings, E. (2005). Ecotourism and indigenous micro-enterprise formation in northern Australia opportunities and constraints. Tourism management, 26(6), 891-904. https://doi.org/10.1016/j.tourman.2004.04.006

Gurung, D. B., \& Seeland, K. (2008). Ecotourism in Bhutan: Extending its benefits to rural communities. Annals of Tourism research, 35(2), 489-508. https://doi.org/10.1016/j.annals.2008.02.004

Ghorbanzadeh, M., \& Niloufar, P. (2019). Categorization of North Khorasan Villages in Terms of Indicators of Entrepreneurial Ecotourism Developments (Case Study: Bojnord-Golestan Road). Journal of Research and Rural Planning, 8(3), 119-132.

Ibrahim, I., Zukhri, N., \& Rendy, R. (2019). Between Tourism and Ecology: Review of Political Policy Commitments on Ecotourism Development in Bangka Belitung. E3S Web of Conferences, 118, 04008.

Juma, C., \& Timmer, V. (2003). Social learning and entrepreneurship: A framework for analyzing the Equator Initiative and the 2002 Equator Prize finalists. Science, Environment and Development Group Website, Kennedy School of Government, Harvard University. Retrieved September, 30, 2009.

Klar, H. W. (2012). Fostering distributed instructional leadership: A sociocultural perspective of leadership development in urban high schools. Leadership and Policy in Schools, 11(4), 365-390.

Lindberg, K., Enriquez, J., \& Sproule, K. (1996). Ecotourism questioned: Case studies from Belize. Annals of tourism research, 23(3), 543-562. https://doi.org/10.1016/0160-7383(95)00074-7

Nugroho, I., Pramukanto, F. H., Negara, P. D., Purnomowati, W., \& Wulandari, W. (2016). Promoting the rural development through the ecotourism activities in Indonesia. American Journal of Tourism Management, 5(1), 918.

Scheyvens, R. (1999). Ecotourism and the empowerment of local communities. Tourism management, 20(2), 245249. https://doi.org/10.1016/S0261-5177(98)00069-7

Otsuki, K. (2007). Paradise in a Brazil nut cemetery: Sustainability discourses and social action in Pará, the Brazilian Amazon. 